\title{
HZSM-35 zeolite catalyzed aldol condensation reaction to prepare acrylic acid and its ester: Effect of its acidic property
}

\author{
Zhanling Ma a,b,c, Xiangang Ma a, Youming Ni a, Hongchao Liu a, Wenliang Zhu a,\#, Xinwen Guo ${ }^{\text {, }}$ \\ Zhongmin Liu a,* \\ a National Engineering Laboratory for Methanol to Olefins, Dalian Institute of Chemical Physics, Chinese Academy of Sciences, Dalian 116023, Liaoning, \\ China \\ b State Key Laboratory of Fine Chemicals, PSU-DUT Joint center for Energy Research, School of Chemical Engineering, Dalian University of Technology, \\ Dalian 116024, Liaoning, China \\ c University of Chinese Academy of Sciences, Beijing 100049, China
}

\section{A R T I C L E I N F O}

\section{Article history:}

Received 21 June 2018

Accepted 16 July 2018

Published 5 November 2018

\section{Keywords:}

Aldol condensation

Methyl acetate

ZSM-35 zeolite

Brönsted acid

Acrylic acid

\begin{abstract}
A B S T R A C T
Acrylic acid (AA) and its ester, methyl acrylate (MA), were produced by a green one-step aldol condensation reaction of dimethoxymethane and methyl acetate. The reaction was conducted over ZSM-35 zeolites with different concentrations of Brönsted acid, which were prepared by the sodium ion-exchange process with H-form zeolite. The acidic property of HZSM-35 was studied in detail through infrared experiments. About $51 \%$ of all bridging $\mathrm{OH}$ groups were distributed in cages, while $23 \%$ and $26 \%$, respectively, were distributed in $10-$ and 8 -ring channels. The catalytic performance was enhanced by a high concentration of Brönsted acid, indicating that Brönsted acid is an active site for the aldol condensation reaction. The ZSM-35 zeolite possessing a concentration of Brönsted acid as high as $0.049 \mathrm{mmol} / \mathrm{g}$ demonstrated excellent performance with a MA+AA selectivity of up to $73 \%$.
\end{abstract}

(C) 2018, Dalian Institute of Chemical Physics, Chinese Academy of Sciences. Published by Elsevier B.V. All rights reserved.

\section{Introduction}

Acrylic acid (AA) and methyl acrylate (MA), the two extremely important industrial chemicals, are widely applied in the production of paintings, coatings, carbon fibers, and adhesives. They are mostly produced by a two-step oxidation reaction of propylene [1-3]. This route of oxidation by air/oxygen incurs a risk of over-oxidation of propylene and the desired products, which limits their widespread application on a large scale. Therefore, a novel and green route for MA and AA synthesis is highly demanded. Recently, the route to produce MA and AA through a one-step aldol condensation reaction of formaldehyde (FA) and methyl acetate (MAc) has been attracting substantial interest from both academic and industrial communities because of its simplicity and common feedstocks that can be derived readily from natural gas, coal, and biomass $[4,5]$.

Aldol condensation reaction, which is catalyzed by acid/base catalysts, can readily occur over either an acid (or a base) or an acid-base bifunctional catalyst. Previous studies have mainly focused on aldol condensation catalyzed by a variety of cesium supported with $\mathrm{SiO}_{2}$ or $\mathrm{SBA}-15$ [6-9], by acid-base bifunctional catalysts such as $\mathrm{V}_{2} \mathrm{O}_{5}-\mathrm{P}_{2} \mathrm{O}_{5}$ binary or $\mathrm{V}_{2} \mathrm{O}_{5}-\mathrm{P}_{2} \mathrm{O}_{5}-\mathrm{SiO}_{2}$ ternary systems [10-13], or by alkali metal oxide-supported acidic catalysts [14-16]. However, there are limited experimental data available for evaluating the performance of solid acid catalysts in the aldol condensation reaction

\footnotetext{
* Corresponding author. Tel: +86-411-84379998; Fax: +86-411-84379038; E-mail: liuzm@dicp.ac.cn \# Corresponding author. Tel: +86-411-84379418; Fax: +86-411-84379038; E-mail: wlzhu@dicp.ac.cn DOI: 10.1016/S1872-2067(18)63145-6 | http://www.sciencedirect.com/science/journal/18722067 | Chin. J. Catal., Vol. 39, No. 11, November 2018
} 
in the gaseous phase. Zeolite catalysts, as a type of solid catalysts being comprehensively utilized for more than $40 \%$ industrial processes in petroleum and petrochemical fields [17], show significant potential in aldol condensation. In our previous study [18], several types of zeolites, including HY, Hß, HMOR, HZSM-5, and HZSM-35, were first used as aldol condensation catalysts for synthesizing MA and AA with high activity, which suggested that zeolite is a catalyst candidate for the aldol condensation reaction of FA and MAc.

It is well known that two types of acids, Brönsted and Lewis acids, exist in zeolites, especially in silica-alumina zeolites. However, the issue of whether the aldol condensation reaction occurs over Lewis acid sites, Brönsted acid sites, or both has not been resolved yet. Jeong et al. [19] reported the results from in situ Fourier-transform infrared spectroscopy (FT-IR) studies of aldol condensation reactions of aldehydes with $\mathrm{AlPO}_{4}$ zeolite as a catalyst. They found that Lewis acid was the active site for the aldol condensation reaction due to the lack of a bridging hydroxyl group in the $\mathrm{AlPO}_{4}$ zeolite catalyst. Panov et al. [20] conducted aldol condensation reactions over nanosized amorphous alumina catalysts containing different amounts of Lewis acid sites and found that the rate of aldol condensation reaction of acetone decreased with the loss of Lewis acid sites. Dumitriu et al. [21] synthesized a series of MFI zeolites by isomorphous substitution of $\mathrm{Me}^{3+}$ for silicon and evaluated them in aldol condensation reactions of acetaldehyde and formaldehyde. They found that both Brönsted and Lewis acids were involved in the reaction and that a higher Lewis acid concentration favored a better selectivity for MFI zeolite catalysts. However, Kikhtyanin et al. [22] proved that solid catalysts with exclusive Lewis acid sites possessed substantially lower activity in the aldol condensation of furfural and acetone with MOFs as acidic catalysts, and suggested that Brönsted acid contributed more to the aldol condensation reaction than Lewis acid. Kikhtyanin et al. [23] also reported that two HBEA samples with the same Brönsted acid concentration but different Lewis acid concentrations exhibited approximately the same activity. They believed that the aldol condensation reaction proceeded with the participation of Brönsted acid rather than Lewis acid.

In our previous studies $[16,18]$, HZSM-35 zeolite was found to perform very well in the aldol condensation reaction of MAc and formaldehyde, and its acid site was found to be indispensable for triggering the reaction. To the best of our knowledge, no information is available yet on the effect of acidic properties of zeolites on the aldol condensation of formaldehyde and MAc to prepare MA and AA. Therefore, here, we study in detail the acidic property of HZSM-35 and prepare ZSM-35 with different concentrations of Brönsted acid through the sodium ion-exchange process without altering the concentration of Lewis acid. We then evaluate the catalytic performance of ZSM-35 zeolites for the aldol condensation reaction of formaldehyde and MAc.

\section{Experimental}

\subsection{Catalyst preparation}

The regents used included dimethoxymethane (DMM) (AR, 98\%, Alfa Aesar (China) Chemicals Co., Ltd.) and MAc (AR, 98\%, Sinopharm Chemical Reagent Co., Ltd., China). Na-ZSM-35 $\left(\mathrm{SiO}_{2} / \mathrm{Al}_{2} \mathrm{O}_{3}=79\right)$ was purchased from Shanghai Novel Chemical Technology Co., Ltd., China. Zeolite was calcinated at $823 \mathrm{~K}$ in air for at least $5 \mathrm{~h}$ to remove the retained organic template, and then converted into an $\mathrm{H}$-form zeolite before use by conducting ion exchange thrice at $353 \mathrm{~K}$ for $6 \mathrm{~h}$ in $1 \mathrm{~mol} / \mathrm{L} \mathrm{NH}_{4} \mathrm{NO}_{3}$ solution, followed by washing with deionized water, drying at $373 \mathrm{~K}$ overnight, and calcination at $823 \mathrm{~K}$ for $4 \mathrm{~h}$. To obtain zeolites with different sodium ion weight percentages, the $\mathrm{H}$-form zeolite powder began to be exchanged with $\mathrm{NaNO}_{3}$ solution $(0.1 \mathrm{~mol} / \mathrm{L})$ at $323 \mathrm{~K}$ with a solid-to-liquid ratio of $1 / 20$ for different times. The filter cake was dried at $373 \mathrm{~K}$ for $12 \mathrm{~h}$. At last, we obtained zeolite with different sodium ion-exchange degrees. The sample was indicated as Na-Z-x, where $\mathrm{x}$ indicates the molar ratio of sodium element to aluminum element in the zeolite characterized by X-ray fluorescence (XRF) results.

\subsection{Catalyst characterization}

FT-IR spectroscopy was conducted at a spectral resolution of $4 \mathrm{~cm}^{-1}$ on a Bruker Tensor 27 FT-IR spectrophotometer equipped with a mercury-cadmium-telluride detector, which was sensitive to $-\mathrm{OH}$ group vibration. The sample was pressed into a self-supporting disk with a diameter of $13 \mathrm{~mm}$. Then, the disk was put into a quartz cell, which was connected to a vacuum system and sealed with $\mathrm{CaF}_{2}$ windows and then heated to $723 \mathrm{~K}$ for at least $4 \mathrm{~h}$ to remove the retained water before collecting the spectra. The pyridine or acetonitrile adsorption was performed by exposing the preheated disk to its vapor. The semi-quantitative analysis of the concentration of Brönsted or Lewis acid is shown as below [24]:

$$
\begin{gathered}
C \text { (pyridine on B sites })=1.88 \mathrm{IA}(\mathrm{B}) R^{2} / W \\
C(\text { pyridine on L sites })=1.42 \mathrm{IA}(\mathrm{L}) R^{2} / W \\
C=\text { concentration }(\mathrm{mmol} / \mathrm{g} \text { catalyst }) \\
\mathrm{IA}(\mathrm{B}, \mathrm{L})=\text { integrated absorbance of B or L band }\left(\mathrm{cm}^{-1}\right) \\
R=\text { radius of catalyst disk }\left(\mathrm{cm}^{-1}\right) \\
W=\text { weight of disk }(\mathrm{mg})
\end{gathered}
$$

The solid-state NMR experiments were carried out on a Bruker AvanceIII 600 spectrometer equipped with a $14.1 \mathrm{~T}$ wide-bore magnet. The bulk acidity of zeolite was determined by temperature-programmed desorption of ammonia ( $\mathrm{NH}_{3}$-TPD) on a Micromeritics AutoChem 2920 instrument. The sample $(0.20 \mathrm{~g})$ was loaded in a U-shaped microreactor and preheated at $823 \mathrm{~K}$ for $0.5 \mathrm{~h}$ under helium atmosphere. After cooling to $373 \mathrm{~K}$, the sample was saturated with ammonia, followed by purging with helium to remove the physically adsorbed ammonia molecule. Ammonia desorption was conducted in helium flow ( $30 \mathrm{~mL} / \mathrm{min}$ ) by heating from 373 to 923 $\mathrm{K}$ at a rate of $10 \mathrm{~K} / \mathrm{min}$ and measured by a thermal conductivity detector.

The crystallinity of the samples was characterized by a PANalytical X'Pert PRO X-ray diffraction (XRD) meter with $\mathrm{Cu}-K_{\alpha}$ radiation $(\lambda=1.51059 \AA)$ at $40 \mathrm{kV}$ and $40 \mathrm{~mA}$. The chemical composition of zeolite was determined by Philips Magix-601 XRF. Nitrogen adsorption-desorption isotherms 


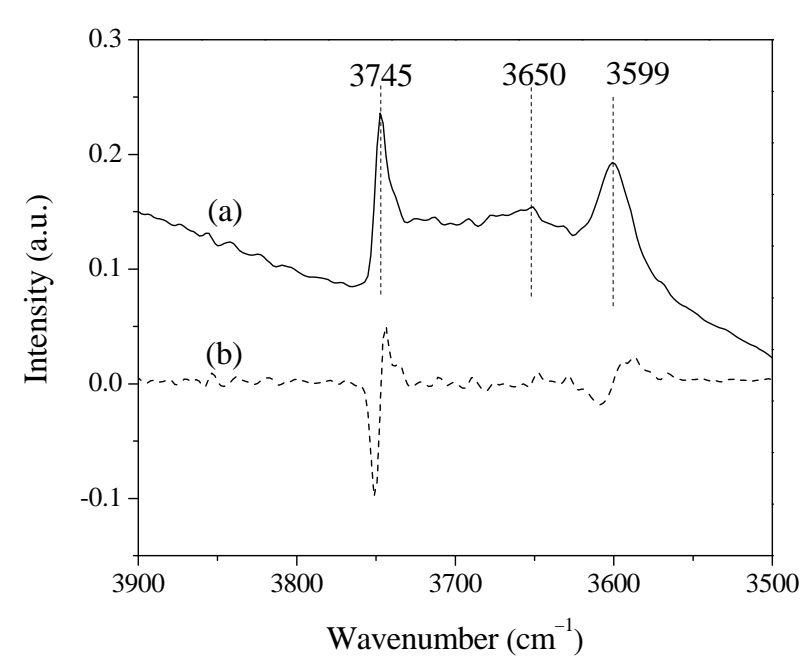

Fig. 1. $\mathrm{OH}$ regions of (a) the IR spectrum of HZSM-35 zeolite measured at $298 \mathrm{~K}$ after evacuation at $723 \mathrm{~K}$ and (b) its first derivative.

were obtained on a Micrometrics ASAP 2020 system at $77 \mathrm{~K}$.

\subsection{Catalytic test}

Aldol condensation of formaldehyde with MAc was carried out at $623 \mathrm{~K}$ with $0.5 \mathrm{~g}$ zeolite (20-40 mesh) in a fixed bed. Here, DMM was applied as the source of formaldehyde. The system pressure was set at $3 \mathrm{MPa}$. DMM and MAc precursors in two separated stainless-steel tubes held at $293 \mathrm{~K}$ were bubbled into the reaction tube by $30 \mathrm{~mL} / \mathrm{min} \mathrm{N}_{2}$ flow, respectively. The products were analyzed using an online gas chromatograph equipped with a flame ionization detector connected to an FFAP capillary column. The yield of MA and AA was defined as molesmA+AA $/$ molesmAc fed and $S_{\text {MA+AA }}$ was calculated using the molesMA+AA/molesmAc consumed.

\section{Results and discussion}

\subsection{Acidity of HZSM-35 zeolite}

FT-IR spectroscopy is applied to characterize the acid property of HZSM-35 zeolite, as shown in Fig. 1. The spectrum of
HZSM-35 zeolite in Fig. 1(a) consists of two distinct bands at $3745 \mathrm{~cm}^{-1}$ due to the terminal silanol groups and at $3599 \mathrm{~cm}^{-1}$ due to the bridging hydroxyl groups (Brönsted acid sites) [25-27]. The relatively high intensity of silanol groups at 3745 $\mathrm{cm}^{-1}$ shows that HZSM-35 zeolite is high-siliceous, which agrees with the XRF result indicating a high $\mathrm{SiO}_{2} / \mathrm{Al}_{2} \mathrm{O}_{3}$ ratio of 79. In addition, a broad band around $3650 \mathrm{~cm}^{-1}$ is assigned to $\mathrm{OH}$ groups adjacent to extra-framework aluminum species. A close examination reveals that hydroxyl IR bands are asymmetric, which is particularly evident from the first derivative of the spectrum. The asymmetry at $3745 \mathrm{~cm}^{-1}$ can be attributed to the presence of terminal silanol groups and to their hydrogen bonding interaction, while that at $3599 \mathrm{~cm}^{-1}$ is associated with the Brönsted acidic bridging hydroxyl moieties vibrating in channels or cages of different sizes [28].

The ${ }^{29}$ Si MAS NMR spectrum of HZSM-35 zeolite in Fig. 2(a) shows three signals at $-105.7,-112.1$, and $-116.6 \mathrm{ppm}$, which are assigned to $\mathrm{Si}(1 \mathrm{Al}) \mathrm{T}_{\mathrm{A}}$, the superposition of $\mathrm{Si}(1 \mathrm{Al}) \mathrm{T}_{\mathrm{A}}$ and $\mathrm{Si}(0 \mathrm{Al}) \mathrm{T}_{\mathrm{B}}$, and $\mathrm{Si}(0 \mathrm{Al}) \mathrm{T}_{\mathrm{B}}$, respectively [29-31]. The high ratio of $\mathrm{Si}(\mathrm{OAl})$ and $\mathrm{Si}(1 \mathrm{Al})$ contributions indicates the prevalence of the Si-O-Si bond in the absence of neighboring Al. Fig. 2(b) shows the ${ }^{27} \mathrm{Al}$ MAS NMR spectrum of HZSM-35 zeolite used here, where the signal at $54.5 \mathrm{ppm}$ is attributed to tetrahedrally coordinated framework aluminum atoms. The signal at $0 \mathrm{ppm}$ indicates the presence of a few octahedrally coordinated extra-framework aluminum species, acting as Lewis acid sites, which is consistent with the FT-IR observation in Fig. 1.

Fig. 3 shows the deconstruction of the bridging $\mathrm{OH}$ band in the IR spectra of HZSM-35 according to Zholobenko et al. [28]. A good fit is obtained by decomposition based on three peaks. The $3610 \mathrm{~cm}^{-1}$ band can be attributed to $\mathrm{Si}-\mathrm{O}(\mathrm{H})$-Al groups in 10 -member rings, amounting to $23 \%$ of $\mathrm{Si}-\mathrm{O}(\mathrm{H})-\mathrm{Al}$ groups. The intense band at $3600 \mathrm{~cm}^{-1}$ can be assigned to the bridging hydroxyl groups in cages at the intersection of 8- and 6-ring channels, amounting to $51 \%$ of the bridging hydroxyl groups. The band at $3588 \mathrm{~cm}^{-1}$ can be attributed to $\mathrm{Si}-\mathrm{O}(\mathrm{H})-\mathrm{Al}$ groups in 8-member rings. Such an assignment coincides with the republished work. For instance, the initially observed band in bridging $\mathrm{OH}$ groups at about $3610 \mathrm{~cm}^{-1}$ in H-mordenite is deconvoluted into two component bands, one at a higher frequency of $3612 \mathrm{~cm}^{-1}$ and another at a lower frequency of 3585
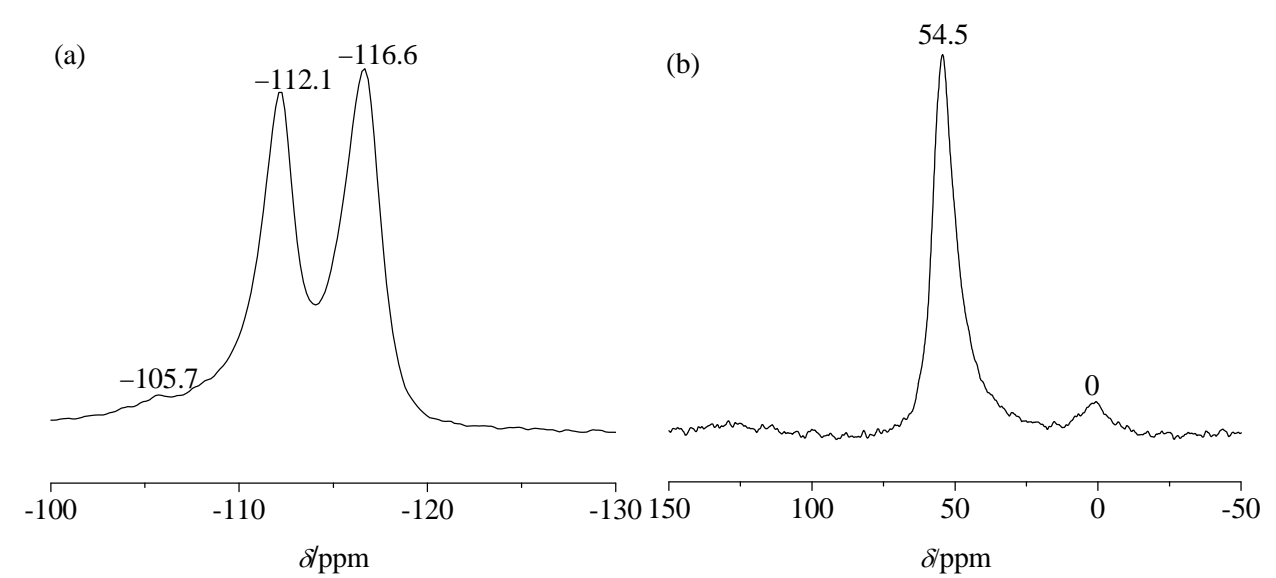

Fig. 2. (a) ${ }^{29} \mathrm{Si}$ and (b) ${ }^{27} \mathrm{Al}$ MAS NMR spectra of HZSM-35 zeolite. 


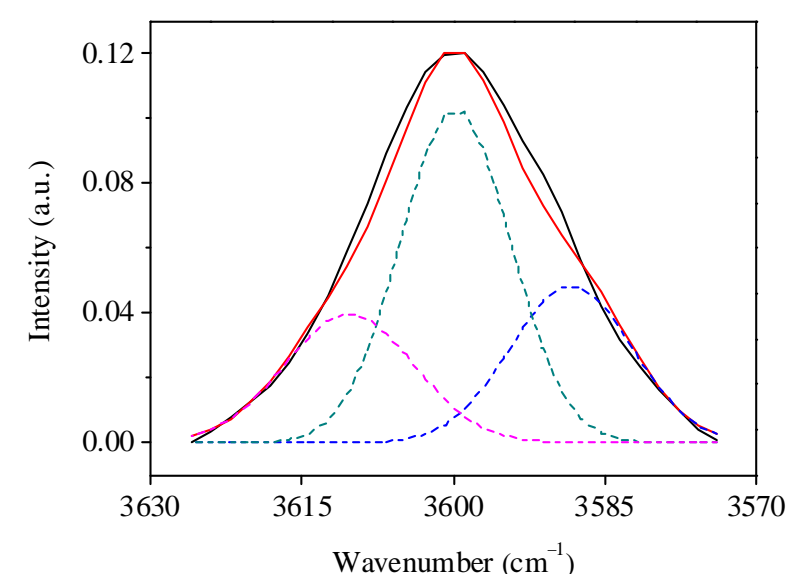

Fig. 3. Deconstruction of the bridging $\mathrm{OH}$ band in the IR spectrum of HZSM-35. (-, experimental spectrum; ..., computed spectrum; - - -, single components).

$\mathrm{cm}^{-1}$, which are assigned to $\mathrm{OH}$ groups in 12- and 8-ring channels, respectively [32-35]. The low-frequency-component IR band is attributed to Brönsted acid sites in a small channel, while the high-frequency one is attributed to those in a large ring, such as 8- or 10-rings [36-38].

Fig. 4(a) describes that pyridine adsorption in HZSM-35 zeolite takes place only on a part of the bridging $\mathrm{OH}$ groups in vacuum at room temperature with a small decrease in intensity at $3599 \mathrm{~cm}^{-1}$, while the smaller acetonitrile molecule interacts with all bridging $\mathrm{OH}$ groups under the same conditions as the intensity at $3599 \mathrm{~cm}^{-1}$ immediately decreases. This in turn proves the heterogeneous distribution of internal bridging $\mathrm{OH}$ groups in HZSM-35 zeolite. The accessibility of the internal Bronsted acidic bridging $\mathrm{OH}$ groups for pyridine molecules is studied with respect to temperature, as shown in Fig. 4(b). The intensity of the IR band at $3599 \mathrm{~cm}^{-1}$ characteristic for strong acidic bridging $\mathrm{OH}$ groups clearly decreases after adsorption at $373 \mathrm{~K}$. With an increase in the temperature of pyridine adsorption, more adsorption of pyridine on bridging $\mathrm{OH}$ groups of HZSM-35 zeolite takes place as follows from a decline in the intensity of the band at $3599 \mathrm{~cm}^{-1}$. This means that the internal bridging $\mathrm{OH}$ groups are accessible to large pyridine molecules at high temperature $[39,40]$. The existence of two bands at 3597 and $3589 \mathrm{~cm}^{-1}$ is revealed after pyridine adsorption at different temperatures. The bridging $\mathrm{OH}$ groups located in the smaller channels are not so easily accessible for large pyridine molecules as those in the main channels. It seems reasonable to assign these two bands at 3597 and $3589 \mathrm{~cm}^{-1}$ to the bridging $\mathrm{OH}$ groups located in cages and 8-ring channels, respectively, which supports our decomposition results shown in Fig. 3.

\subsection{Effect of the concentration of Brönsted acid on catalytic performance}

Zeolites, which are crystalline alumino-silicate microporous materials, possess interesting intrinsic acidic features, such as Lewis and Brönsted acid sites. Brönsted acid sites exist as bridging $\mathrm{OH}$ groups to $\mathrm{Al}$ and $\mathrm{Si}$ atoms, and their protons can be exchanged with other metal cations. Herein, we prepare ZSM-35 zeolites with varying concentrations of Brönsted acid through the sodium ion-exchange process. The crystalline structure and textural property are not affected by the exchange process, as shown in Fig. S1 and S2.

The IR characterization is used to clarify the change in the acidic properties of zeolites after the treatment. The intensity of the bridging $\mathrm{OH}$ groups at $3599 \mathrm{~cm}^{-1}$ suffers a significant decrease after sodium ion exchange, as illustrated in Fig. 5(a), which indicates that the Brönsted acidic proton of HZSM-35 zeolite is substituted by $\mathrm{Na}^{+}$. A higher exchange degree leads to a lower intensity of the Brönsted acid hydroxyl groups. In HZSM-35 zeolite, the IR band of $\mathrm{PyH}^{+}$appears at $1545 \mathrm{~cm}^{-1}$ after adsorption of pyridine at $623 \mathrm{~K}$ for $30 \mathrm{~min}$ with the band of pyridine adsorbed on typical Lewis acid sites at $1445 \mathrm{~cm}^{-1}$ (Fig. 5(b)) [41,42]. The Lewis acid sites in HZSM-35 are assigned to the extra-framework aluminum species. The intensity of the band at $1545 \mathrm{~cm}^{-1}$ drops significantly with the pretreatment of the sodium ion-exchange process, which indicates a decrease in the concentration of Brönsted acid in ZSM-35 zeolite. As shown in Table 1, the concentration of the Brönsted acid in HZSM-35 zeolite, obtained by the integration of the band at $1545 \mathrm{~cm}^{-1}$, is $0.049 \mathrm{mmol} / \mathrm{g}$, which decreases to $0.037 \mathrm{mmol} / \mathrm{g}$ in Na-Z-25 zeolite and even falls to $0.011 \mathrm{mmol} / \mathrm{g}$ in Na-Z-49
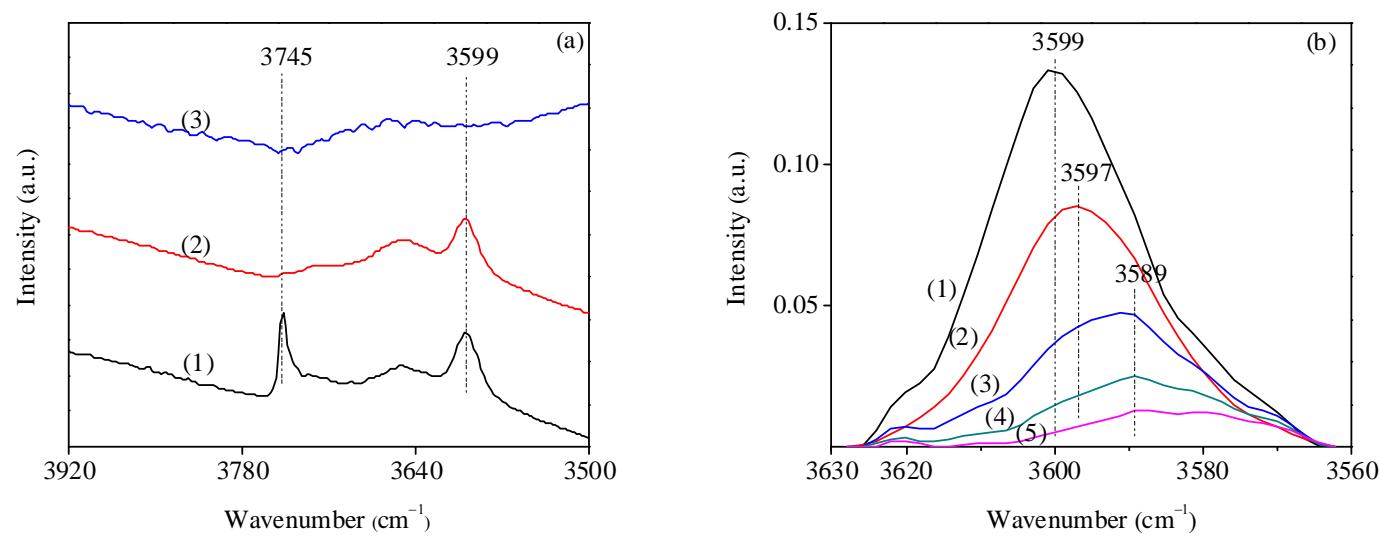

Fig. 4. (a) FT-IR spectra of OH groups of HZSM-35 at $298 \mathrm{~K}$ after evacuation at $723 \mathrm{~K}$ (1), after adsorption of pyridine at $298 \mathrm{~K}$ (2), and after adsorption of acetonitrile at $298 \mathrm{~K}$ (3). (b) FT-IR spectra of the bridging OH groups of HZSM-35 (1), after adsorption of pyridine at $373 \mathrm{~K}$ (2), $523 \mathrm{~K}$ (3), 623 $\mathrm{K}(4)$, and $723 \mathrm{~K}(5)$. 

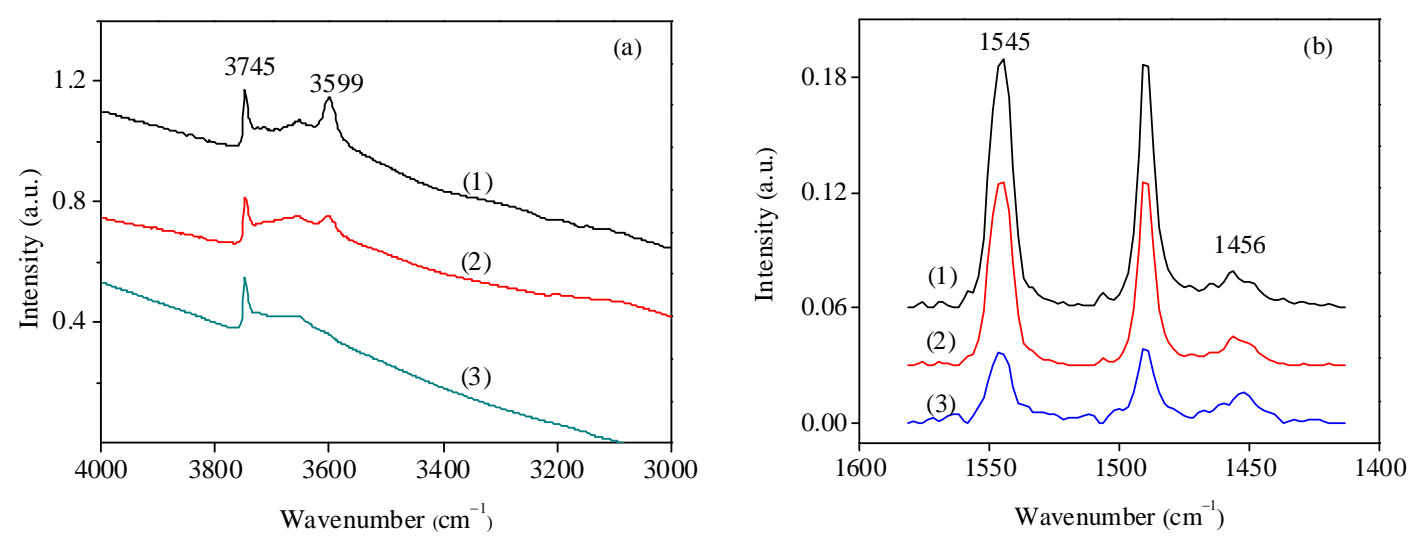

Fig. 5. (a) FT-IR characterization of OH regions of HZSM-35 zeolite (1) and Na-Z-25 (2) and Na-Z-49 (3) at 298 K after evacuation at 723 K; (b) Pyridine adsorption at $623 \mathrm{~K}$ for $30 \mathrm{~min}$ and desorption at the same time of HZSM-35 zeolite (1) and Na-Z-25 (2) and Na-Z-49 (3).

zeolite. The concentration of the Lewis acid remains constant at $0.004 \mathrm{mmol} / \mathrm{g}$.

The effect of this sodium ion-exchange process on the bulk acidity of zeolite is studied using $\mathrm{NH}_{3}-\mathrm{TPD}$, as described in Fig. 6. Two ammonia desorption peaks are found at 465 and $709 \mathrm{~K}$ in HZSM-35 (Fig. 6(a)), which shows that two types of acid sites, including the weak and the strong ones, exist in the sample. The intensity of the latter peak suffers a decrease in Na-Z-25 zeolite, and even becomes a broad tail in Na-Z-49 zeolite. Note that the strength of the strong acid does not change in the sodium ion-exchange process for its peak temperature being maintained constant at $709 \mathrm{~K}$. Taken together, the above results show that a large amount of strong Brönsted acid is substituted by the sodium ion, resulting in a loss of strong acidity in HZSM-35 zeolite.

The performance of ZSM-35 zeolites with different concentrations of Brönsted acid in the aldol condensation reaction of FA and MAc is evaluated in a continuous-flow fixed-bed reaction tube as illustrated in Fig. 7. Herein, dimethoxymethane (DMM) is employed as the source of FA. The mass spectrum detection result shown in Fig. S3 substantiates the facile decomposition of DMM to attain FA with $100 \%$ conversion in Fig. S4 over all ZSM-35 zeolites. MAc conversion changes slightly over all ZSM-35 zeolites, as shown in Fig. S4. However, the yield and $S_{\mathrm{MA}+\mathrm{AA}}$ are remarkably enhanced parallel to the increase in the concentration of Brönsted acid in zeolites. Here, note that AA is mainly derived from the hydrolysis of MA and the ratio of MA to AA varies from 1 to 4 . Given that the concentration of Lewis acid remains constant at $0.004 \mathrm{mmol} / \mathrm{g}$ for all zeolites, it is suggested that Brönsted acid is an active site for the aldol condensation reaction of DMM and MAc. The rate-determined step of aldol condensation reaction in the gaseous phase is re-

Table 1

Acidic properties of ZSM-35 zeolites after sodium ion-exchange treatment.

\begin{tabular}{lccc}
\hline Sample & $\mathrm{SiO}_{2} / \mathrm{Al}_{2} \mathrm{O}_{3}$ & $\mathrm{~B}^{*}(\mathrm{mmol} / \mathrm{g})$ & $\mathrm{L}^{*}(\mathrm{mmol} / \mathrm{g})$ \\
\hline HZSM-35 & 79 & 0.049 & 0.004 \\
Na-Z-25 & 79 & 0.037 & 0.004 \\
Na-Z-49 & 82 & 0.011 & 0.004 \\
\hline
\end{tabular}

* Calculated through integration of IR peak. ported to be the keto-enol tautomerization of MAc. The enol form of MAc reacts with FA to produce MA and AA. With a high concentration of Brönsted acid, the keto-enol tautomerization equilibrium might shift significantly to an enol counterpart, which consecutively reacts with FA to give a high $S_{\mathrm{MA}+\mathrm{AA}}$ and yield.

The deposited coke amounts of deactivated ZSM-35 zeolites with different concentrations of Brönsted acid after aldol condensation reaction for $6 \mathrm{~h}$ are determined by TGA characterization. As shown in Fig. 8, the TGA results show that the amounts of deposited coke in HZSM-35, Na-Z-25, and Na-Z-49 are 8\%, $5.5 \%$, and $2.5 \%$, respectively, among which HZSM-35 zeolite has the highest coke amount. Considering the difference in Brönsted acid concentration of the three catalysts, the lowest amount of coke within Na-Z-49 zeolite is ascribed to its low concentration of Brönsted acid. From the first derivative curve of TGA, the consumption temperatures of coke species within HZSM-35, Na-Z-25, and Na-Z-49 zeolites are 904, 860, and 819 $\mathrm{K}$, respectively. HZSM-35 zeolite has the hardest coke species, which mainly consists of benzene, naphthalene, phenanthrene, and their methyl-substituted derivatives, as described in Fig. S5. The unsaturated product, MA and AA, might continue to perform the Diels-Alder ring-closing reaction on Brönsted acid sites to form aromatic species. On the other hand, the methanol-to-hydrocarbons reaction is unavoidable at such high reac-

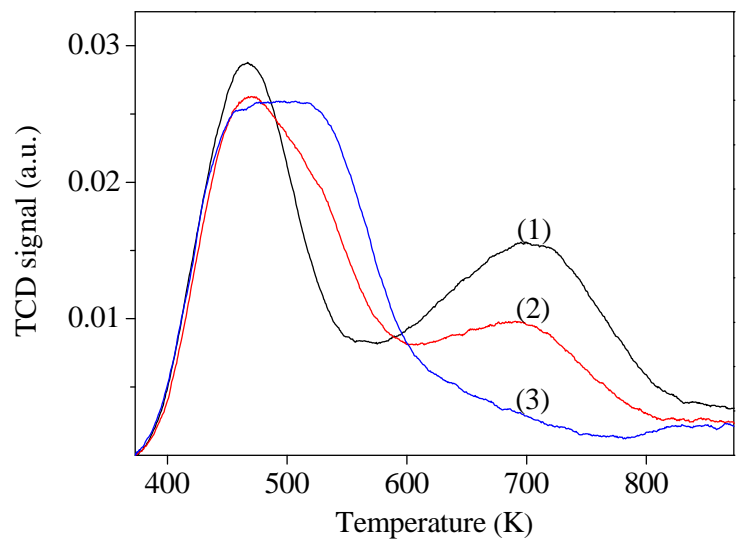

Fig. 6. $\mathrm{NH}_{3}$-TPD curves of HZSM-35 (1), Na-Z-25 (2), and Na-Z-49 (3). 

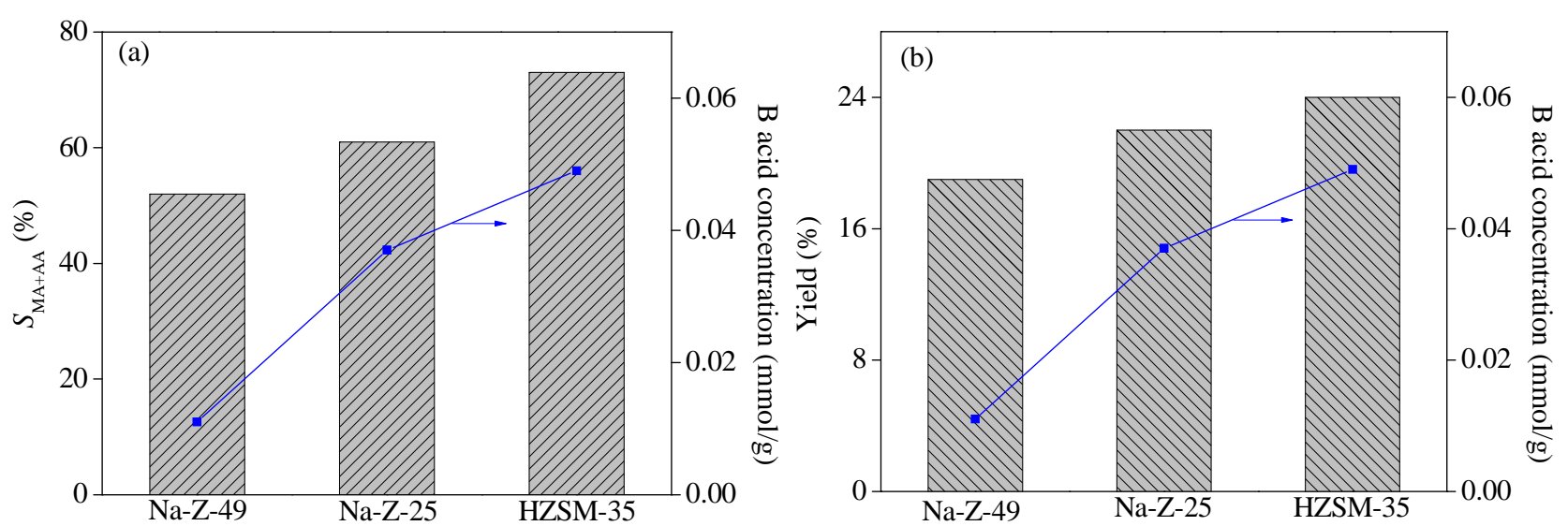

Fig. 7. Effect of the concentration of Brönsted acid of ZSM-35 zeolite on $S_{\mathrm{MA}+\mathrm{AA}}$ (a) and yield (b). Reaction conditions: TOS = $150 \mathrm{~min}, 3 \mathrm{MPa}$, $623 \mathrm{~K}$; the saturated vapor pressures of DMM and MAc were 43.3 and $23.0 \mathrm{kPa}$, respectively; $n_{\mathrm{DMM}} / n_{\mathrm{MAc}}=2 / 1 ; \mathrm{SiO}_{2} / \mathrm{Al}_{2} \mathrm{O}_{3}=79$; and the total gas flow rate was 60 $\mathrm{mL} / \mathrm{min}$.

tion temperature of $623 \mathrm{~K}$ in the presence of a strong Brönsted acid and an amount of $\mathrm{C}_{1}-\mathrm{C}_{5}$ hydrocarbon product is detected in the initial period of the first $60 \mathrm{~min}$. This reaction might also cause the deactivation of zeolites.

\section{Conclusions}

The distribution of Brönsted acid in HZSM-35 zeolite was systemically studied by IR experiments, and $51 \%$ of the total Brönsted acid was found to be located in the cage, while $23 \%$ and $26 \%$ were distributed in 10- and 8-ring channels, respectively. Brönsted acid was an active site for aldol condensation reaction of DMM and MAc for producing MA and AA. A high concentration of Brönsted acid was beneficial to the selectivity and yield of MA and AA. This study provided more information about the acid-catalyzed aldol condensation reaction. Moreover, the accurate position of the site of aldol condensation reaction in the framework, whether in a cage or in a 10- or 8-ring channel, as well as the effect of Lewis acid sites, need to be studied further.

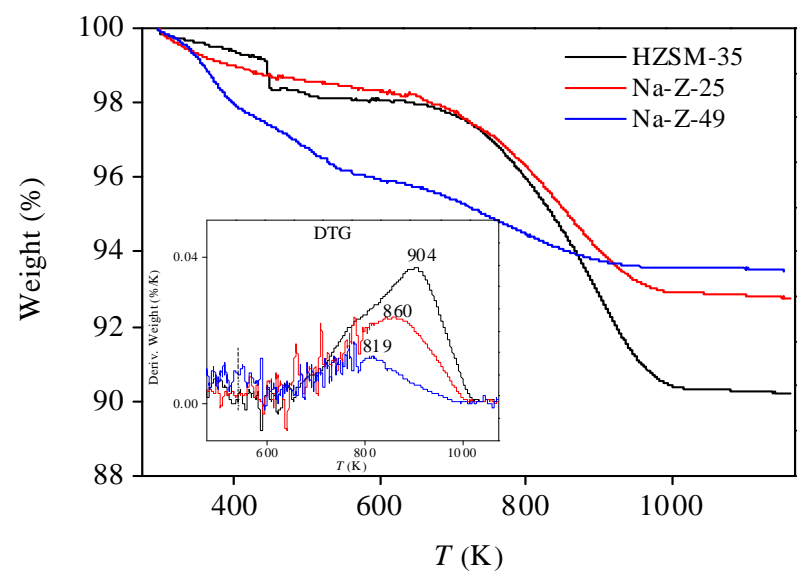

Fig. 8. TGA curves and their derivates (the inset graph) of deactivated HZSM-35, Na-Z-25, and Na-Z-49 zeolites obtained after the aldol condensation reaction of DMM and MAc at $623 \mathrm{~K}$.

\section{References}

[1] M. M. Bettahar, G. Costentin, L. Savary, J. C. Lavalley, Appl. Catal. A, 1996, 145, 1-48.

[2] W. Fang, Q. J. Ge, J. F. Yu, H. Y. Xu, Ind. Eng. Chem. Res., 2011, 50, 1962-1967.

[3] W. E. Campbell, E. L. McDaniel, W. H. Reece, J. E. Williams, H. S. Young, Ind. Eng. Chem. Prod. Res. Develop., 1970, 9, 325-334.

[4] J. F. Vitcha, V. A. Sims, Ind. Eng. Chem. Prod. Res. Develop., 1966, 5, 50-53.

[5] L. H. Zhao, J. Yan, L. C. Wei, Y. L. Jiang, Mod. Chem. Ind., 2015, 35, 44-49.

[6] B. Harris, Ingenia, 2010, 45, 18-23.

[7] Y. N. Wang, X. W. Lang, G. Q. Zhao, H. H. Chen, Y. W. Fan, L. Q. Yu, X. X. Ma, Z. R. Zhu, RSC Adv., 2015, 5, 32826-32834.

[8] J. B. Yan, C. L. Zhang, C. L. Ning, Y. Tang, Y. Zhang, L. L. Chen, S. Gao, Z. L. Wang, W. X. Zhang, J. Ind. Eng. Chem., 2015, 25, 344-351.

[9] T. He, Y. X. Qu, J. D. Wang, Ind. Eng. Chem. Res., 2018, 57, 2773-2786.

[10] H. Zhao, C. C. Zuo, D. Yang, C. S. Li, S. J. Zhang, Ind. Eng. Chem. Res., 2016, 55, 12693-12702.

[11] D. Yang, C. Sararuk, K. Suzuki, Z. X. Li, C. S. Li, Chem. Eng. J., 2016, 300, 160-168.

[12] J. Hu, Z. P. Lu, H. B. Yin, W. P. Xue, A. L. Wang, L. Q. Shen, S. X. Liu, J. Ind. Eng. Chem., 2016, 40, 145-151.

[13] D. Yang, D. Li, H. Y. Yao, G. L. Zhang, T. T. Jiao, Z. X. Li, C. S. Li, S. J. Zhang, Ind. Eng. Chem. Res., 2015, 54, 6865-6873.

[14] C. Sararuk, D. Yang, G. L. Zhang, C. S. Li, S. J. Zhang, J. Ind. Eng. Chem., 2017, 46, 342-349.

[15] A. L. Wang, J. Hu, H. B. Yin, Z. P. Lu, W. P. Xue, L. Q. Shen, S. X. Liu, RSC Adv., 2017, 7, 48475-48485.

[16] Z. L. Ma, X. G. Ma, H. C. Liu, W. L. Zhu, X. W. Guo, Z. M. Liu, Chin. J. Catal., 2018, 39, 1129-1137.

[17] K. Tanabe, W. F. Hölderich, Appl. Catal. A, 1999, 181, 399-434.

[18] Z. L. Ma, X. G. Ma, H. C. Liu, Y. L. He, W. L. Zhu, X. W. Guo, Z. M. Liu, Chem. Commun., 2017, 53, 9071-9074.

[19] M. S. Jeong, H. Rrei, J. Mol. Catal. A, 2000, 156, 245-253.

[20] A. G. Panov, J. J. Fripiat, Catal. Lett., 1999, 57, 25-32.

[21] E. Dumitriu, V. Hulea, I. Fechete, A. Auroux, J. F. Lacaze, C. Guimon, Microporous Mesoporous Mater., 2001, 43, 341-359.

[22] O. Kikhtyanin, D. Kubička, J. Čejka, Catal. Today, 2015, 243, 158-162. 


\title{
Graphical Abstract
}

Chin. J. Catal., 2018, 39: 1762-1769 doi: 10.1016/S1872-2067(18)63145-6

HZSM-35 zeolite catalyzed aldol condensation reaction to prepare acrylic acid and its ester: Effect of its acidic property

Zhanling Ma, Xiangang Ma, Youming Ni, Hongchao Liu,

Wenliang Zhu *, Xinwen Guo, Zhongmin Liu *

Dalian Institute of Chemical Physics, Chinese Academy of Sciences;

Dalian University of Technology;

University of Chinese Academy of Sciences

Brönsted acid was an active site for aldol condensation reaction of DMM and MAc to produce MA and AA. The selectivity of MA and AA increased with the concentration of Brönsted acid.

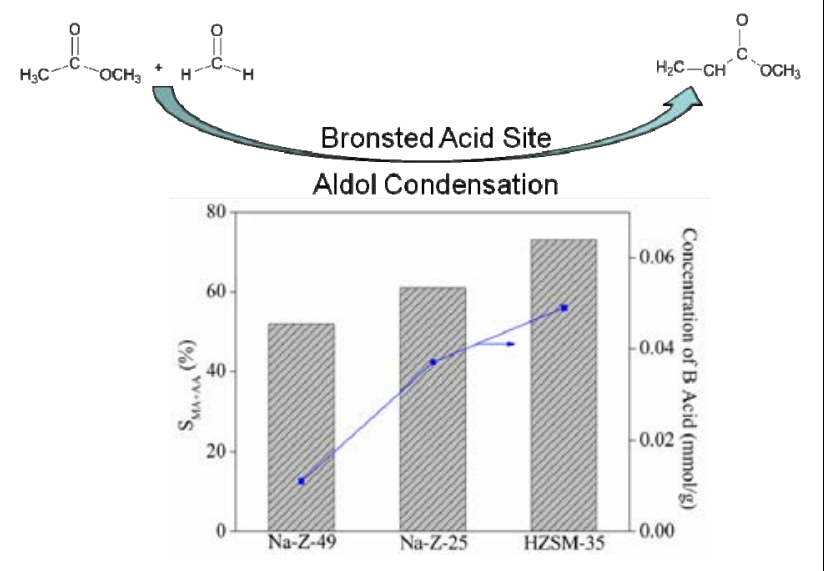

97, 5962-5964.

[34] S. Bordiga, C. Lamberti, F. Geobaldo, A. Zecchina, G. Turnes Palomino, C. Otero Arean, Langmuir, 1995, 11, 527-533.

[35] P. A. Jacobs, W. J. Mortier, Zeolites, 1982, 2, 226-230.

[36] J. E. Naber, K. P. de Jong, W. H. J. Stork, H. P. C. E. Kuipers, M. F. M. Post, Stud. Surf. Sci. Catal., 1994, 84, 2197-2219.

[37] B. Wichterlová, N. Žilkova, E. Uvarova, J. Čejka, P. Sarv, C. Paganini, J. A. Lercher, Appl. Catal. A, 1999, 182, 297-308.

[38] J. Datka, M. Kawalek, K. Gora-Marek, Appl. Catal. A, 2003, 243, 293-299.

[39] M. Trombetta, G. Busca, J. Catal., 1999, 187, 521-523.

[40] J. A. Z. Pieterse, S. Veefkind-Reyes, K. Seshan, L. Domokos, J. A. Lercher, J. Catal., 1999, 187, 518-520.

[41] Z. G. Zhu, H. Xu, J. G. Jiang, Y. J. Guan, P. Wu, J. Catal., 2017, 352, $1-12$.

[42] Z. G. Zhu, H. Xu, J. G. Jiang, X. Liu, J. H, Ding, P. Wu, Appl. Catal. A, 2016, 519, 155-164.

\section{HZSM-35分子耖酸性质对甲缩醛和乙酸甲酯着醛缩合反应的影响}

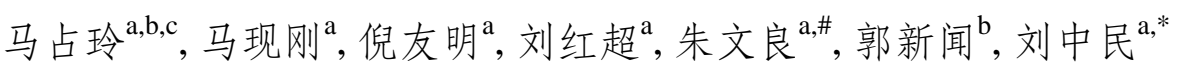 \\ a中国科学院大连化学物理研究所甲醇制烯烃国家工程实验室, 辽宁大连 116023 \\ ${ }^{b}$ 大连理工大学化工与环境生命学部化工学院精细化工国家重点实验室, 辽宁大连116024 \\ c中国科学院大学, 北京100049
}

摘要: 丙烯酸及其酯是重要的化工原料, 广泛应用于涂料、粘结剂、纤维等领域, 目前工业上常采用丙烯两段氧化法进行 制备, 但该法以石油基原料丙烯为源头, 采用 $\mathrm{V} / \mathrm{Mo} / \mathrm{Bi}$ 等金属催化剂, 不符合可持续发展理念, 且存在环境污染及氧气下产 物易过度氧化等问题. 如何高效、安全、大规模工业化制备丙烯酸及其酯是研究者追求的目标. 以乙酸甲酯(Mac)和甲醛 为原料, 通过羟醛缩合一步制备丙烯酸及其酯是一条完全不同于丙烯氧化法的合成路径, 原料均可由煤基甲醇得到, 符合 我国“富煤、贫油、少气”基本能源结构, 且该方法碳原子利用率为 $100 \%$, 副产物仅为水, 属于绿色环保合成路径.

本文以甲缩醛(DMM)为甲醛源, 创新性地采用固体硅铝分子篎为酸性催化剂, 催化DMM和MAc发生羟醛缩合反应来 制备丙烯酸. 硅铝分子篮具有较高的活性, 可高效地催化羟醛缩合反应, 且具有很好的再生性能, 即使催化剂寿命较短, 也 可采用流化床或移动床等反应器进行工业化, 因此具有良好的工业化前景. 硅铝分子篎中常含有Brönsted酸和Lewis酸, 为 试图说明羟醛缩合反应的真正活性位点, 我们以羟醛缩合反应性能最佳的HZSM-35分子篎为研究目标. 
首先, 利用红外研究HZSM-35分子篎的酸性质. 发现分子笁中桥羟基提供Brönsted酸, 外骨架铝物种提供Lewis酸. 通 过对桥羟基红外峰一阶求导, 发现其对称性较差, 表明Brönsted酸在HZSM-35分子篮孔道中分布不均匀. 利用红外分峰手 段, 得知约 $51 \%$ 的Brönsted酸分布于八元环和六元环交叉所形成的笼(cage)中, 约 $23 \%$ 分布于十元环孔道, 26\%分布于八元环 孔道中. 同时, 利用吡啶在分子笁HZSM-35不同温度下的吸附情况验证了这一分峰结果. 其次, 利用钠离子交换方法制备 不同Brönsted酸浓度的ZSM-35分子笁, 经吡啶红外表征得知, Brönsted酸浓度随钠离子交换程度增加而逐渐降低, 而Lewis 酸浓度并未改变; 在差醛缩合反应性能中, 丙烯酸及丙烯酸甲酯选择性和收率均随Brönsted酸浓度增加而逐渐升高, 考虑到 Lewis酸浓度并未变化, 可知Brönsted酸是羟醛缩合反应性能的活性位点, 其浓度增加有利于羟醛缩合反应性能的提高. 同 时, 对比不同ZSM-35分子笁失活现象, 高Brönsted酸浓度时分子笁重积炭量最高, 这可能是由于Brönsted催化不饱和产物关 环生成芳烃物种或(和)发生氢转移过程所导致.

关键词: 羟醛缩合反应; 乙酸甲酯; HZSM-35分子笁; Brönsted位; 丙烯酸

收稿日期: 2018-06-21. 接受日期: 2018-07-16. 出版日期: 2018-11-05.

*通讯联系人. 电话: (0411)84379998; 传真: (0411)84379038; 电子信箱: liuzm@dicp.ac.cn

\#通讯联系人. 电话: (0411)84379418; 传真: (0411)84379038; 电子信箱: wlzhu@dicp.ac.cn

本文的电子版全文由Elsevier出版社在ScienceDirect上出版(http://www.sciencedirect.com/science/journal/18722067). 